\title{
In Vitro Acaricidal Activity of Selected Medicinal Plants Traditionally Used against Ticks in Eastern Ethiopia
}

\author{
Jelalu Kemal ${ }^{(D)}{ }^{1}$ Tesfaheywet Zerihun $\left(\mathbb{D},{ }^{1}\right.$ Sisay Alemu $\left(\mathbb{D},{ }^{1}\right.$ Kedir Sali, ${ }^{1}$ Musa Nasir, ${ }^{1}$ \\ Ashebr Abraha $\otimes^{(1,}{ }^{1}$ and Teka Feyera ${ }^{2}$ \\ ${ }^{1}$ College of Veterinary Medicine, Haramaya University, P.O. Box 138, Dire Dawa, Ethiopia \\ ${ }^{2}$ Department of Animal Science, School of Environmental and Rural Science, University of New England, Armidale, \\ NSW 2351, Australia
}

Correspondence should be addressed to Jelalu Kemal; jelaluk@gmail.com

Received 3 September 2019; Revised 10 December 2019; Accepted 28 January 2020; Published 18 February 2020

Academic Editor: D. S. Lindsay

Copyright (c) 2020 Jelalu Kemal et al. This is an open access article distributed under the Creative Commons Attribution License, which permits unrestricted use, distribution, and reproduction in any medium, provided the original work is properly cited.

\begin{abstract}
A study was carried out to evaluate the acaricidal activities of crude methanolic extract of leaves of six medicinal plants, namely, Vernonia amygdalina, Calpurnia aurea, Schinus molle, Ricinus communis, Croton macrostachyus, and Nicotiana tabacum, against Rhipicephalus (Boophilus) decoloratus and Rhipicephalus pulchellus using an in vitro adult immersion test. Five graded concentrations of the crude extracts, $6.25,12.5,25,50$, and $100 \mathrm{mg} / \mathrm{ml}$, were tested at different time intervals, and temporal changes in tick viability were recorded for 24 hours. Diazinon $(0.1 \%)$ and distilled water were used as positive and negative controls, respectively. Standard procedures were applied to screen the phytochemical constituents of the tested plant parts. Phytochemical screening showed the presence of a condensed amount of tannins in all extracts. Starting from 30 min post exposure, the $100 \mathrm{mg} / \mathrm{ml}$ concentration of $C$. aurea and $R$. communis extracts has caused significantly higher mortality $(P<0.05)$ compared to the diazinon. A significant increase in tick mortality started $2 \mathrm{hr}$ post exposure with diazinon and $50 \mathrm{and} 100 \mathrm{mg} / \mathrm{ml}$ concentrations of $S$. molle. Vernonia amygdalina extract and diazinon showed a significant increase in tick mortality $3 \mathrm{hr}$ post exposure with $100 \mathrm{mg} / \mathrm{ml}$ concentration. Similarly, a significant increase in tick mortality started $2 \mathrm{hr}$ post exposure with diazinon and $100 \mathrm{mg} / \mathrm{ml}$ concentrations of C. macrostachyus and N. tabacum. At $24 \mathrm{hr}$ post exposure, diazinon and 50 and $100 \mathrm{mg} / \mathrm{ml}$ concentrations of all the extracts have caused significantly higher tick mortality than the rest of the concentrations $(P<0.05)$. Higher concentrations of all the extracts had showed a comparable and strong acaricidal effect on Rhipicephalus (Boophilus) decoloratus and Rhipicephalus pulchellus having no significant difference with that of the positive control $(P>0.05)$ at $24 \mathrm{hr}$ post exposure period. Tick killing activity of all evaluated plant extracts increases with increasing exposure time and concentration as well. Thus, all the tested plants could be used against Rhipicephalus (Boophilus) decoloratus and Rhipicephalus pulchellus as a potential alternative to substitute commercially available drugs. We recommend further study on fractionating each component separately and validating the materials.
\end{abstract}

\section{Introduction}

Ticks are destructive blood-sucking ectoparasites of livestock and wild animals causing huge economic losses, thus creating food insecurity [1], with an estimated global cost of control and productivity losses of 7 billion USD per year [2]. Their effects are diverse, including reduced growth and milk production, paralysis/toxicosis, and transmission of tick-borne diseases (TBDs) that reduce production or cause mortality [3].
Worldwide tick control is based mainly on the repeated use of acaricides, which have resulted in problems related to environmental pollution, milk and meat contamination, and the development of resistance leading to increased cost of control [4]. In Ethiopia, over the past decades, ticks are mainly controlled by using a variety of synthetic acaricides [5]. However, ticks have developed resistance against commercial acaricides in Ethiopia with the widespread, underor overconcentrated, and frequent use of these compounds $[6,7]$. Thus, there is an urgent need for new tick control 
strategies to overcome the drawback associated with the use of synthetic drugs. One alternative control strategy could be phytotherapy, an important component of ethnoveterinary medicine [8].

The use of natural products, mainly acaricides from the botanical source used for the control of ticks, has been the focus of research in many countries, principally to withstand the noticeable increasing frequency of acaricide-resistant tick strains. The use of botanicals for the control of ticks is compatible with traditional practices in Africa, including Ethiopia where most resource-poor farmers use plant materials to treat ectoparasites and endoparasites of livestock [2]. Acaricidal activity of crude extracts from different plants against ticks has been reported [9-13]. The phytoextracts produce acaricidal properties through diverse mechanisms: killing adult ticks, reducing tick feeding, and inhibition of egg hatching, molting, fecundity, and viability of eggs $[8,14,15]$.

In far rural parts of the country including eastern Hararghe, modern veterinary drugs including synthetic acaricides are not affordable to the majority of poor livestock owners. Even when accessible, the owners tend to treat their livestock with synthetic products in a haphazard way, and misuse of chemicals illegally imported at a high cost from neighboring countries is increasing year after year. Furthermore, there is a continuous complain from the livestock keepers over the poor efficacy of most of the existing acaricidal drugs. As a result, livestock raisers continue to rely on ethnoveterinary knowledge and practices for socially acceptable, inexpensive, and locally available remedies for managing ticks and other ectoparasites affecting their livestock. Additional fact that desires due attention is that livestock owners claim a number of botanicals having acaricidal effect which need scientific evaluation by using standardized parasitological procedures.

Thus, it is quite rightly convincing that evaluating acaricidal efficacy of natural remedies can greatly contribute to control tick invasion in a cheaper and more sustainable way. Moreover, there is a great potential to develop sources of acaricides from the available medicinal plants which can be easily produced by livestock producers themselves or processed by cottage industries and used as cheap and efficient natural biocide for tick control [1]. Implementing an effective tick control strategy suitable to a specific livestock production system is a dual harvest, controlling ticks and also the TBDs. Therefore, it is necessary to undertake an acaricidal efficacy evaluation of botanicals traditionally used by the livestock owners as an alternative tick management strategy. The present work was aimed at evaluating the acaricidal activity of crude extracts of leaves of six medicinal plants traditionally used by livestock raisers as an alternative tick control strategy in eastern Hararghe, Ethiopia. The plants tested in the current biological activity assay include Vernonia amygdalina, Calpurnia aurea, Schinus molle, Ricinus communis, Croton macrostachyus, and Nicotiana tabacum leaf extracts against Rhipicephalus (Boophilus) decoloratus and Rhipicephalus pulchellus for antitick activity.

\section{Materials and Methods}

2.1. Study Design. This study employed an experimental study design: an in vitro immersion method as described by Vongkhamchanh et al. [15].

2.2. Collection and Identification of the Plant Materials. The plants were selected based on the scientific and ethnomedical information in the literature complemented with a preliminary ethnobotanical survey during collection from their natural habitats. The candidate plants that were included for the experiment were V. amygdalina (Girawa/Dhebichaa), S. molle (Mirmir/Muka libaanataa), C. aurea (Digita/Ceekaa), R. communis (Gulo/Qobboo), C. macrostachyus (Bisana/Makannisa), and N. tabacum (Tumbahoo/Tamboo). The selected plants were collected, identified, and verified with taxonomical studies as reported by [16]. To reduce possible contamination, especially by fungi, latex gloves were worn during leaf collection.

2.3. Crude Extract Preparation. Fresh leaves of the plants were separately cleaned with tap water to remove dirt and soil particles, shade dried at room temperature for two weeks, mechanically grinded, and coarsely powdered using an electric grinder. The powdered specimen was then subjected to extraction using $80 \%$ methanol by a cold maceration technique. A total of $500 \mathrm{~g}$ of the pounded materials was separately soaked in each extraction solvent ( $100 \mathrm{~g}$ of powder in $400 \mathrm{ml}$ of solvent) followed by shaking periodically for three days and then filtered. This was repeated three times to allow the solvents extract substantial quantities of the chemical constituents from the pounded plant materials. The mixture was first filtered using gauze, and then, the filtrate was passed through sterile filter paper (Whatman No. 1, Whatman Ltd. England). Then, the filtered extract was kept overnight in a hot air oven at a temperature of $60^{\circ} \mathrm{C}$ to obtain the pure crude extracts. The extraction rate (\%) was calculated as follows:

$$
\begin{aligned}
& \text { Extraction rate }(\%) \\
& \qquad=\frac{\text { Weight of extracts }(\mathrm{g})}{\text { Weight of the plant material }(\mathrm{g}) \text { before extraction }} \times 100 .
\end{aligned}
$$

The resulting extracts were then transferred into welllabeled vials and kept in a refrigerator until required for use.

2.4. Phytochemical Screening. Phytochemical screening was carried out to assess the qualitative chemical composition of crude extracts using commonly employed precipitation and coloration reaction to identify the major natural chemical groups and secondary metabolites present in the plants. Combinations of several methods were used to identify the phytochemicals of the medicinal plants. Standard screening tests were conducted using a conventional protocol and reagents on the methanolic extracts of herbs to identify the constituents as described by Sofowora [17]. The screening was done to detect the presence of bioactive principle believed to have acaricidal activities: saponins, tannins, 
flavonoids, steroids, phenolic compounds, alkaloids, glycosides, and triterpenes.

2.5. Study Parasite Collection, Transportation, and Identification. Ticks were collected from naturally infested cattle in Haramaya (Finkille, Adelle) and Harar (Erer, Dire Teyara), Eastern Ethiopia. For collection of ticks, the entire body surface of the animals was examined thoroughly, and adult ticks were collected from the body of the animals where they were available. Collected ticks were put in vials and were wrapped in cotton net gauze for oxygen supply and transported and identified in Haramaya University College of Veterinary Medicine, Parasitology Laboratory. All collected ticks from naturally infested cattle were examined under a stereomicroscope and identified according to [18].

\subsection{Acaricidal Activity Evaluation}

2.6.1. Preparation of Concentrations of Crude Methanolic Extracts. The dried extracts were diluted in distilled water at the concentrations required for the bioassays $(6.25 \mathrm{mg} / \mathrm{ml}$, $12.5 \mathrm{mg} / \mathrm{ml}, 25 \mathrm{mg} / \mathrm{ml}, 50 \mathrm{mg} / \mathrm{ml}$, and $100 \mathrm{mg} / \mathrm{ml}$ ) for all tested plants. The concentrations were used for the acaricidal efficacy test. Distilled water was used as the negative control while $0.1 \%$ diazinon was used as the positive control. The positive control, $0.1 \%$ diazinon 60 EC (Adamitulu Pesticides Processing, Ethiopia), was diluted in water according to the manufacturer's recommendation $(1: 1000)$ before being used for further experiment [19].

2.6.2. Adult Immersion Test. The in vitro tests were started within one hour after tick collection [19]. Ten active live adult ticks in three replications were put into the Petri dish, and $3 \mathrm{ml}$ of each concentration was directly added to the three replicated Petri dishes for $2 \mathrm{~min}$ of exposure. After immersion, the ticks were filtered with filter paper and placed in separate Petri dishes [20]. Three millilitres of distilled water and $0.1 \%$ diazinon $60 \mathrm{EC}$ were used as the negative and positive controls, respectively. The Petri dishes were incubated at $28^{\circ} \mathrm{C}$ with $80 \%$ relative humidity, and each tick in each Petri dish was closely observed for any death under a stereomicroscope at $30 \mathrm{~min}, 1 \mathrm{hr}, 2 \mathrm{hr}, 3 \mathrm{hr}, 6 \mathrm{hr}, 12 \mathrm{hr}$, and $24 \mathrm{hr}$ time intervals [21]. The viability of ticks was checked regularly by stimulation with a needle, and ticks were recorded as dead if no reaction was shown. The percentage mortality was calculated by using a formula given by Krishnaveni and Venkatalakshmi [22] as follows:

$$
\text { Mortality\% }=\frac{\text { Number of dead ticks }}{\text { Total number of ticks }} \times 100
$$

2.7. Data Analysis. Collected raw data was stored in a Microsoft Excel database system used for data management. SPSS Windows version 20 was used for data analysis. Mean tick mortality and related results of the study were expressed using descriptive statistics (mean \pm standard error of mean, percentage, and graph). One way analysis of variance (ANOVA) followed by Tukey's HSD multiple comparisons was used to compare differences between different in vitro groups. All significant levels are set at $P<0.05$.
TABLE 1: Yield of methanolic crude extracts of all selected medicinal plant leaf.

\begin{tabular}{lcc}
\hline Plant name & Yield in gram & Yield in $\%$ \\
\hline C. aurea & 62 & 20.67 \\
S. molle & 58 & 19.33 \\
V. amygdalina & 36 & 12 \\
R. communis & 72 & 30.67 \\
C. macrostachyus & 68 & 29.3 \\
N. tabacum & 46 & 22 \\
\hline
\end{tabular}

\section{Result}

3.1. Percentage Extraction Yield and Phytochemical Constituents. Table 1 summarizes the percentage extraction yields of $500 \mathrm{~g}$ powder of leaves of each plant. Each extract had a dark brown color and sticky and semisolid consistence. The highest and lowest percentage yields obtained were $30.67 \%$ and $12 \%$ for R. communis and V. amygdalina, respectively. The phytochemical constituents detected in the resultant crude extracts are shown in Table 2. Phytochemical screening showed the presence of condensed tannins and alkaloids in all extracts.

3.2. In Vitro Acaricidal Activity of the Plant Extracts against Rh. decoloratus and pulchellus. A significant increase in tick mortality started $3 \mathrm{hr}$ post exposure with $100 \mathrm{mg} / \mathrm{ml}$ concentration of C. aurea extract and diazinon and $12 \mathrm{hr}$ post exposure with $50 \mathrm{mg} / \mathrm{ml}$ concentration of the C. aurea extract. Starting from $30 \mathrm{~min}$ post exposure, the $100 \mathrm{mg} / \mathrm{ml}$ concentration of $C$. aurea extract has caused significantly higher mortality compared to the diazinon $(P<0.05)$. At $24 \mathrm{hr}$ post exposure period, diazinon and 50 and $100 \mathrm{mg} / \mathrm{ml}$ concentrations of the extract have caused significantly higher tick mortality compared with the rest of the concentrations below $25 \mathrm{mg} / \mathrm{ml}(P<0.05)$. The least concentration $(6.25 \mathrm{mg} / \mathrm{ml})$ has caused significantly higher mortality when compared with the negative control (distilled water) at $24 \mathrm{hr}$ exposure time.

A significant increase in tick mortality started $2 \mathrm{hr}$ post exposure with diazinon and 50 and $100 \mathrm{mg} / \mathrm{ml}$ concentrations of $S$. molle and $12 \mathrm{hr}$ post exposure with $6.25,12.5$, and $25 \mathrm{mg} / \mathrm{ml}$ concentrations of $S$. molle extract. At $24 \mathrm{hr}$ post exposure period, 25,50 , and $100 \mathrm{mg} / \mathrm{ml}$ concentrations of the extract and diazinon had a comparable tick killing effect compared with the rest of the concentrations below $12.5 \mathrm{mg} / \mathrm{ml}$. However, the three higher concentrations of the extracts and diazinon had no significant difference in their effect on the parasite $(P>0.05)$.

Starting from $3 \mathrm{hr}$ post exposure with $100 \mathrm{mg} / \mathrm{ml}$ concentration of $V$. amygdalina leaf extract and diazinon, there showed a significant increase in tick mortality. Starting from $12 \mathrm{hr}$ post exposure, the $6.25 \mathrm{mg} / \mathrm{ml}$ concentration of $V$. amygdalina extract has caused significantly higher mortality compared to the distilled water (negative control) $(P<0.05)$. At $24 \mathrm{hr}$ post exposure period, diazinon and 25 , 50 , and $100 \mathrm{mg} / \mathrm{ml}$ concentrations of the extract have caused 
TABLE 2: Qualitative determinations of active ingredients in crude extracts of different plants.

\begin{tabular}{lcccccc}
\hline Ingredients & C. aurea & S. molle & V. amygdalina & R. communis & C. macrostachyus & N. tabacum \\
\hline Saponin & + & - & + & + & + & + \\
Tannin & + & + & - & + & - & + \\
Phenolic compounds & + & - & - & + & + & + \\
Steroids & + & - & - & + & + & + \\
Flavonoids & + & - & - & + & + & + \\
Phlobatannin & + & - & - & - & - & + \\
Glycosides & - & - & + & - & + \\
Triterpenes & + & + & & + \\
Alkaloids & & & & + & + \\
\hline
\end{tabular}

Note: +: present; -: negative.

significantly higher tick mortality than the rest of the concentrations below $12.5 \mathrm{mg} / \mathrm{ml}(P<0.05)$ (Figure 1 ).

A significant increase in tick mortality started $2 \mathrm{hr}$ post exposure with $100 \mathrm{mg} / \mathrm{ml}$ concentration of $R$. communis extract and diazinon and $3 \mathrm{hr}$ post exposure with $100 \mathrm{mg} / \mathrm{ml}$ concentration of the extract. At $24 \mathrm{hr}$ post exposure period, diazinon and 50 and $100 \mathrm{mg} / \mathrm{ml}$ concentrations of the extract have caused significantly higher tick mortality than the rest of the concentrations below $25 \mathrm{mg} / \mathrm{ml}(P<0.05)$. The least concentration $(6.25 \mathrm{mg} / \mathrm{ml})$ has caused significantly higher mortality when compared with the negative control at $24 \mathrm{hr}$ exposure time (Figure 1).

Tick mortality was significantly increased starting from $2 \mathrm{hr}$ and in $3 \mathrm{hr}$ post exposure of $100 \mathrm{mg} / \mathrm{ml}$ concentrations C. macrostachyus and diazinon, respectively. At the $24 \mathrm{hr}$ post exposure period, 50 and $100 \mathrm{mg} / \mathrm{ml}$ concentrations of the $C$. macrostachyus extract and diazinon had a comparable tick killing effect than the rest of the concentrations below $25 \mathrm{mg} / \mathrm{ml}$ (Figure 1).

At the $24 \mathrm{hr}$ post exposure period, diazinon and 50 and $100 \mathrm{mg} / \mathrm{ml}$ concentrations of the $N$. tabacum extract have caused significantly higher tick mortality than the rest of the concentrations below $25 \mathrm{mg} / \mathrm{ml}(P<0.05)$. However, the three higher concentrations of the extract and diazinon had no significant difference in their effect on the parasite. Moreover, there is no significant difference between the three higher concentrations tested ( $\geq 50 \mathrm{mg} / \mathrm{ml}$ ) (Figure 1).

The mean mortality \pm standard errors of mean of $R h .(B)$. decoloratus and $R h$. pulchellus at minute/hour post exposure with different concentrations of C. aurea, S. molle, V. amygdalina, R. communis, C. macrostachyus, and N. tabacum was showed in Tables 3-8. The findings indicated that both $C$. aurea and $S$. molle showed $8.33 \pm 0.33$ mortality whereas $V$. amygdalina, $R$. communis, C. macrostachyus, and N. tabacum showed $7.67 \pm 0.33,7.3 \pm 0.33,7.3 \pm 0.33$, and $7.67 \pm$ 0.33 , respectively, mortality effect after $24 \mathrm{hr}$ of exposure to $100 \mathrm{mg} / \mathrm{ml}$ concentrations (Tables 3-8).

\section{Discussion}

This study revealed that there was a difference yield percentage of extracts among the plants. The leaf of $R$. communis presented the highest yield (30.67\%) among extracts followed by C. macrostachyus (29.3\%) while the lowest (12\%) was observed for the leaf of $V$. amygdalina (Table 1). This finding was in contrary with Askale [11] who reported 9.3\% methanolic leaf extract of $R$. communis. Some differences on the percentage yield of these extract materials among the plants might be due to the difference on the nature of plant species. The different results may be also due to chemical composition differences of the extracts, different environmental conditions which create differences in phytochemical constitution, and harvest time. Furthermore, the solvents and test protocols used during extraction promote difference in concentrations and classes of secondary bioactives present in extracts [23].

In the phytochemical screening test, $C$. aurea (leaf) was found positive for alkaloids, saponins, phlobatannin, steroids, flavonoids, glycosides, phenolic compounds, and tannins, while negative for triterpenes (Table 2). This finding is in consistency with Dula and Zelalem [13] who found all the listed active ingredients using different standard tests and Umer et al. [24] who reported the presence of alkaloids, tannins, flavonoids, and saponins. Other study showed that extract of $C$. aurea leaves was found positive for alkaloids [25] and phenolic compounds [26]. The crude extract of S. molle (leaf) was positive for tannins and alkaloids while negative for saponins, steroids, flavonoids, glycosides, phlobatannin, phenolic compounds, and triterpenes which is in line with a similar study by Magadum et al. [27] who reported the presence of tannins. This finding was inconsistence with Ribeiro et al. [28] who reported the presence of saponin.

Leaf extracts of $V$. amygdalina contained saponins, tannins, phenolic compound, flavonoids, and alkaloids while negative for steroids, phlobatannins, glycosides, and triterpenes. This finding is similar with Ayoola et al. [29] who reported the presence of saponins and phenolic compounds. Another study by Adebayo et al. [30] also demonstrated that $V$. amygdalina contain tannins, flavonoids, and alkaloids and by Alemu et al. [31] reported the presence of saponin, phenolic compounds, flavonoids, and alkaloids. Phytochemical screening of leaf extracts of $R$. communis revealed that the plant contained saponins, tannins, phenolic compounds, steroids, flavonoids, glycosides, triterpenes, phlobatannin, and alkaloids. The current findings are similar to those reported 
Calpurnia aurea

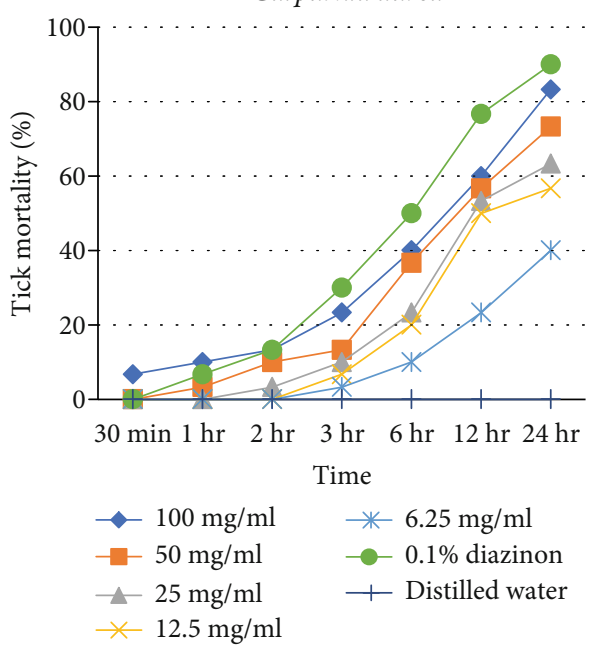

Vernonia amygdalina

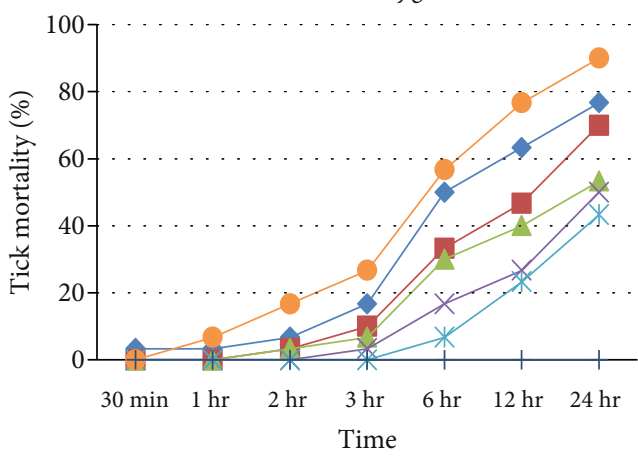

$\rightarrow 100 \mathrm{mg} / \mathrm{ml} \quad * 6.25 \mathrm{mg} / \mathrm{ml}$

$-50 \mathrm{mg} / \mathrm{ml}$

$-25 \mathrm{mg} / \mathrm{ml}$

$\leftarrow 12.5 \mathrm{mg} / \mathrm{ml}$

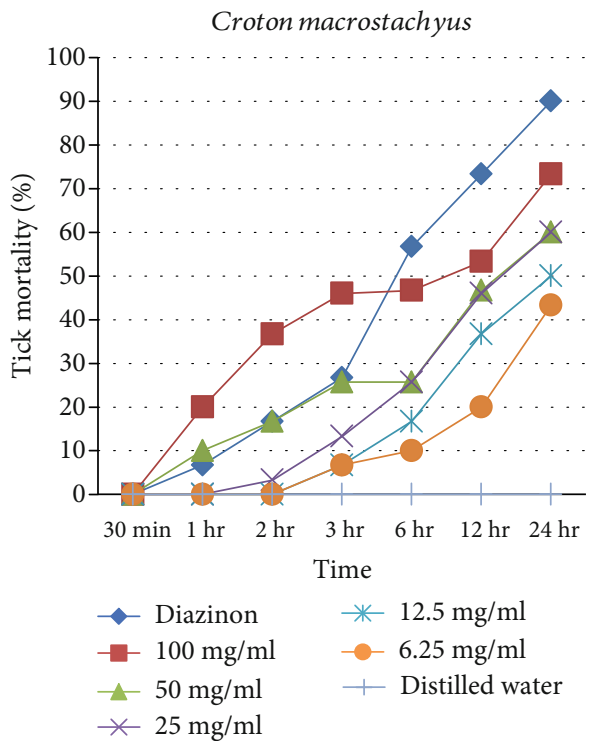

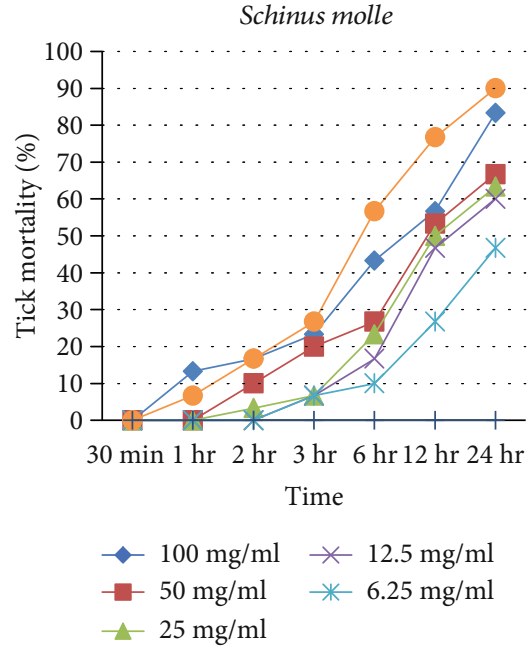
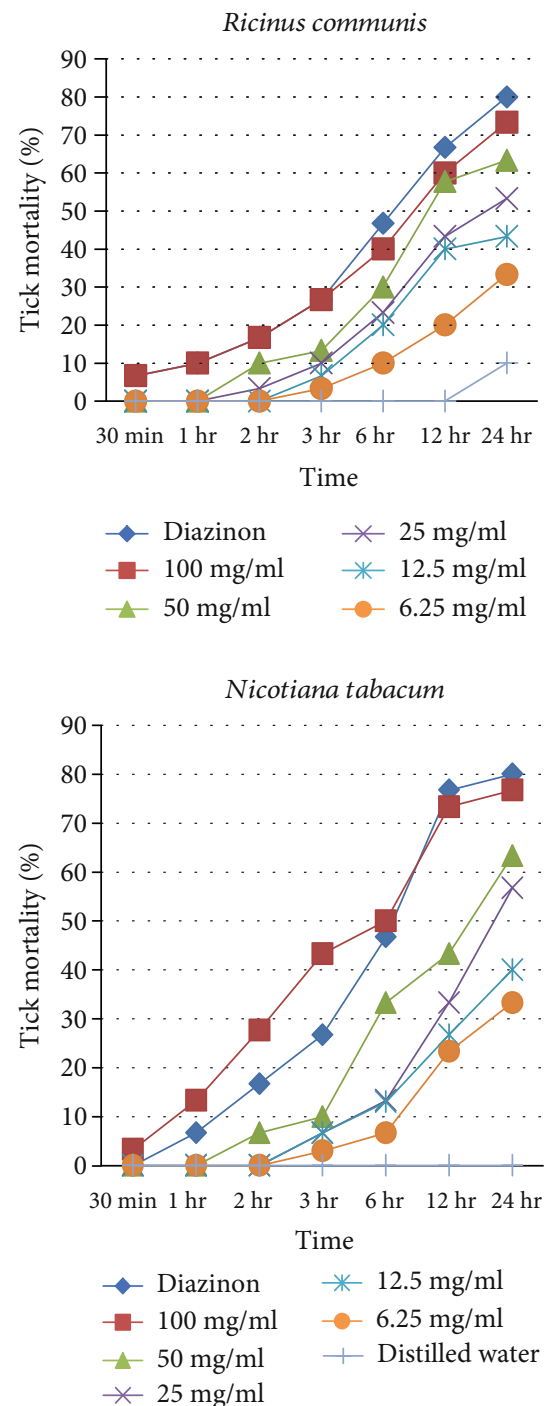

FIGURE 1: Mortalities of ticks treated with methanolic extracts of selected medicinal plants.

previously by Singh et al. [32] but different with the findings of Kumar et al. [33] who reported the absence of alkaloids in leaf extracts of $R$. communis. Differences in climatic condi- tions, tests used, the cultivation, and collection of plant materials for extract production may cause differences in results [34]. Growth conditions of the plants also determine the 
TABLE 3: In vitro tick killing effect of methanolic extract of Calpurnia aurea against $R h .(B)$. decoloratus.

\begin{tabular}{|c|c|c|c|c|c|c|c|}
\hline \multirow{2}{*}{ Extract concentration $(\mathrm{mg} / \mathrm{ml})$} & \multicolumn{7}{|c|}{ Mean number of ticks dead (mean of mortality \pm SE) at minute/hour post exposure } \\
\hline & $30 \mathrm{~min}$ & $1 \mathrm{hr}$ & $2 \mathrm{hr}$ & $3 \mathrm{hr}$ & $6 \mathrm{hr}$ & $12 \mathrm{hr}$ & $24 \mathrm{hr}$ \\
\hline 100 & $0.67 \pm 0.33^{\mathrm{b}}$ & $1.00 \pm 0.00^{\mathrm{b}}$ & $1.33 \pm 0.33^{\mathrm{b}}$ & $2.33 \pm 0.33^{\mathrm{bc}}$ & $4.00 \pm 0.57^{\mathrm{de}}$ & $6.00 \pm 0.57^{\mathrm{c}}$ & $8.33 \pm 0.33^{\mathrm{de}}$ \\
\hline 50 & $0.00 \pm 0.00^{\mathrm{a}}$ & $0.33 \pm 0.33^{\mathrm{ab}}$ & $1.00 \pm 0.00^{\mathrm{ab}}$ & $1.33 \pm 0.33^{\mathrm{ab}}$ & $3.67 \pm 0.33^{\text {cde }}$ & $5.67 \pm 0.33^{\mathrm{c}}$ & $7.33 \pm 0.33^{\text {cde }}$ \\
\hline 25 & $0.00 \pm 0.00^{\mathrm{a}}$ & $0.00 \pm 0.00^{\mathrm{a}}$ & $0.33 \pm 0.33^{\mathrm{ab}}$ & $1.00 \pm 0.00^{\mathrm{ab}}$ & $2.33 \pm 0.33^{b c d}$ & $5.33 \pm 0.33^{c}$ & $6.33 \pm 0.33^{\mathrm{bcd}}$ \\
\hline 12.5 & $0.00 \pm 0.00^{\mathrm{a}}$ & $0.00 \pm 0.00^{\mathrm{a}}$ & $0.00 \pm 0.00^{\mathrm{ab}}$ & $0.67 \pm 0.33^{\mathrm{a}}$ & $2.00 \pm 0.00^{b c}$ & $5.00 \pm 0.00^{c}$ & $5.67 \pm 0.33^{b c}$ \\
\hline 6.25 & $0.00 \pm 0.00^{\mathrm{a}}$ & $0.00 \pm 0.00^{\mathrm{a}}$ & $0.00 \pm 0.00^{\mathrm{a}}$ & $0.33 \pm 0.33^{\mathrm{a}}$ & $1.00 \pm 0.00^{\mathrm{ab}}$ & $2.33 \pm 0.33^{\mathrm{b}}$ & $4.33 \pm 1.45^{\mathrm{b}}$ \\
\hline $0.1 \%$ diazinon & $0.00 \pm 0.00^{\mathrm{a}}$ & $0.67 \pm 0.33^{\mathrm{ab}}$ & $1.67 \pm 0.33^{\mathrm{b}}$ & $2.67 \pm 0.33^{c}$ & $5.67 \pm 0.33^{\mathrm{e}}$ & $7.67 \pm 0.33^{\mathrm{d}}$ & $9.00 \pm 0.00^{\mathrm{e}}$ \\
\hline Distilled water & $0.00 \pm 0.00^{\mathrm{a}}$ & $0.00 \pm 0.00^{\mathrm{a}}$ & $0.00 \pm 0.00^{\mathrm{a}}$ & $0.00 \pm 0.00^{\mathrm{a}}$ & $0.00 \pm 0.00^{\mathrm{a}}$ & $0.00 \pm 0.00^{\mathrm{a}}$ & $0.00 \pm 0.00^{\mathrm{a}}$ \\
\hline
\end{tabular}

Means followed by the same letter on the same column are not significantly different by ANOVA $(P>0.05)$.

TABLe 4: In vitro tick killing effect of methanolic extract of Schinus molle against Rh. (B). decoloratus.

\begin{tabular}{|c|c|c|c|c|c|c|c|}
\hline \multirow{2}{*}{ Extract concentration $(\mathrm{mg} / \mathrm{ml})$} & \multicolumn{7}{|c|}{ Mean number of ticks dead (mean of mortality \pm SE) at minute/hour post exposure } \\
\hline & $30 \mathrm{~min}$ & $1 \mathrm{hr}$ & $2 \mathrm{hr}$ & $3 \mathrm{hr}$ & $6 \mathrm{hr}$ & $12 \mathrm{hr}$ & $24 \mathrm{hr}$ \\
\hline 100 & $0.00 \pm 0.00$ & $1.33 \pm 0.33^{\mathrm{a}}$ & $1.67 \pm 0.33^{\mathrm{b}}$ & $2.33 \pm 0.33^{\mathrm{bc}}$ & $4.33 \pm 0.33^{\mathrm{d}}$ & $5.67 \pm 0.33^{\mathrm{cd}}$ & $8.33 \pm 0.33^{\mathrm{cd}}$ \\
\hline 50 & $0.00 \pm 0.00$ & $0.00 \pm 0.00^{\mathrm{a}}$ & $1.0 \pm 0.00^{\mathrm{ab}}$ & $2.0 \pm 0.57^{\mathrm{bc}}$ & $2.67 \pm 0.33^{\mathrm{c}}$ & $5.33 \pm 0.33^{\mathrm{c}}$ & $6.67 \pm 0.33^{\mathrm{bc}}$ \\
\hline 25 & $0.00 \pm 0.00$ & $0.00 \pm 0.00^{\mathrm{a}}$ & $0.33 \pm 0.33^{\mathrm{a}}$ & $0.67 \pm 0.33^{\mathrm{ab}}$ & $2.33 \pm 0.33^{b c}$ & $5.0 \pm 0.57^{c}$ & $6.33 \pm 0.33^{b c}$ \\
\hline 12.5 & $0.00 \pm 0.00$ & $0.00 \pm 0.00^{\mathrm{a}}$ & $0.00 \pm 0.00^{\mathrm{a}}$ & $0.67 \pm 0.33^{\mathrm{ab}}$ & $1.67 \pm 0.33^{b c}$ & $4.67 \pm 0.33^{b c}$ & $6.0 \pm 0.57^{\mathrm{b}}$ \\
\hline 6.25 & $0.00 \pm 0.00$ & $0.00 \pm 0.00^{\mathrm{a}}$ & $0.00 \pm 0.00^{\mathrm{a}}$ & $0.67 \pm 0.33^{\mathrm{ab}}$ & $1.00 \pm 0.00^{\mathrm{ab}}$ & $2.67 \pm 0.67^{\mathrm{b}}$ & $4.67 \pm 0.88^{\mathrm{b}}$ \\
\hline $0.1 \%$ diazinon & $0.00 \pm 0.00$ & $0.67 \pm 0.33^{\mathrm{a}}$ & $1.67 \pm 0.33^{\mathrm{b}}$ & $2.67 \pm 0.33^{c}$ & $5.67 \pm 0.33^{\mathrm{d}}$ & $7.67 \pm 0.33^{\mathrm{d}}$ & $9.00 \pm 0.00^{\mathrm{d}}$ \\
\hline Distilled water & $0.00 \pm 0.00$ & $0.00 \pm 0.00^{\mathrm{a}}$ & $0.00 \pm 0.00^{\mathrm{a}}$ & $0.00 \pm 0.00^{\mathrm{a}}$ & $0.00 \pm 0.00^{\mathrm{a}}$ & $0.00 \pm 0.00^{\mathrm{a}}$ & $0.00 \pm 0.00^{\mathrm{a}}$ \\
\hline
\end{tabular}

Means followed by the same letter on the same column are not significantly different by ANOVA $(P>0.05)$.

TABLE 5: In vitro tick killing effect of methanolic extract of Vernonia amygdalina against $R h$. (B). decoloratus.

\begin{tabular}{|c|c|c|c|c|c|c|c|}
\hline \multirow{2}{*}{ Extract concentration $(\mathrm{mg} / \mathrm{ml})$} & \multicolumn{7}{|c|}{ Mean number of ticks dead (mean of mortality \pm SE) at minute/hour post exposure } \\
\hline & $30 \mathrm{~min}$ & $1 \mathrm{hr}$ & $2 \mathrm{hr}$ & $3 \mathrm{hr}$ & $6 \mathrm{hr}$ & $12 \mathrm{hr}$ & $24 \mathrm{hr}$ \\
\hline 100 & $0.33 \pm 0.33^{\mathrm{a}}$ & $0.33 \pm 0.33^{\mathrm{a}}$ & $0.67 \pm 0.33^{\mathrm{ab}}$ & $1.67 \pm 0.33^{\mathrm{cd}}$ & $5.00 \pm 0.58^{\mathrm{cd}}$ & $6.33 \pm 0.33^{\mathrm{de}}$ & $7.67 \pm 0.33^{\mathrm{bc}}$ \\
\hline 50 & $0.00 \pm 0.00^{\mathrm{a}}$ & $0.00 \pm 0.00^{\mathrm{a}}$ & $0.33 \pm 0.33^{\mathrm{ab}}$ & $1.00 \pm 0.00^{\mathrm{abc}}$ & $3.33 \pm 0.33^{\mathrm{bc}}$ & $4.67 \pm 0.33^{\mathrm{cd}}$ & $7.00 \pm 0.58^{\mathrm{bc}}$ \\
\hline 25 & $0.00 \pm 0.00^{\mathrm{a}}$ & $0.00 \pm 0.00^{\mathrm{a}}$ & $0.00 \pm 0.00^{\mathrm{a}}$ & $0.67 \pm 0.33^{\mathrm{bc}}$ & $3.00 \pm 0.58^{\mathrm{b}}$ & $4.00 \pm 0.58^{\mathrm{bc}}$ & $5.33 \pm 0.33^{\mathrm{b}}$ \\
\hline 12.5 & $0.00 \pm 0.00^{\mathrm{a}}$ & $0.00 \pm 0.00^{\mathrm{a}}$ & $0.00 \pm 0.00^{\mathrm{a}}$ & $0.33 \pm 0.33^{\mathrm{ab}}$ & $1.67 \pm 0.33^{\mathrm{ab}}$ & $2.67 \pm 0.67^{\mathrm{bc}}$ & $5.00 \pm 0.58^{\mathrm{b}}$ \\
\hline 6.25 & $0.00 \pm 0.00^{\mathrm{a}}$ & $0.00 \pm 0.00^{\mathrm{a}}$ & $0.00 \pm 0.00^{\mathrm{a}}$ & $0.00 \pm 0.00^{\mathrm{a}}$ & $0.67 \pm 0.33^{\mathrm{a}}$ & $2.33 \pm 0.33^{\mathrm{b}}$ & $4.33 \pm 1.67^{\mathrm{b}}$ \\
\hline $0.1 \%$ diazinon & $0.00 \pm 0.00^{\mathrm{a}}$ & $0.67 \pm 0.33^{\mathrm{a}}$ & $1.67 \pm 0.33^{\mathrm{b}}$ & $2.67 \pm 0.33^{\mathrm{d}}$ & $5.67 \pm 0.33^{\mathrm{d}}$ & $7.67 \pm 0.33^{\mathrm{e}}$ & $9.00 \pm 0.00^{c}$ \\
\hline Distilled water & $0.00 \pm 0.00^{\mathrm{a}}$ & $0.00 \pm 0.00^{\mathrm{a}}$ & $0.00 \pm 0.00^{\mathrm{a}}$ & $0.00 \pm 0.00^{\mathrm{a}}$ & $0.00 \pm 0.00^{\mathrm{a}}$ & $0.00 \pm 0.00^{\mathrm{a}}$ & $0.00 \pm 0.00^{\mathrm{a}}$ \\
\hline
\end{tabular}

Means followed by the same letter on the same column are not significantly different by ANOVA $(P>0.05)$.

TABLE 6: In vitro tick killing effect of methanolic extract of Ricinus communis against $R h$. pulchellus.

\begin{tabular}{|c|c|c|c|c|c|c|c|}
\hline \multirow{2}{*}{ Extract concentration $(\mathrm{mg} / \mathrm{ml})$} & \multicolumn{7}{|c|}{ Mean number of ticks dead (mean of mortality \pm SE) at minute/hour post exposure } \\
\hline & $30 \mathrm{~min}$ & $1 \mathrm{hr}$ & $2 \mathrm{hr}$ & $3 \mathrm{hr}$ & $6 \mathrm{hr}$ & $12 \mathrm{hr}$ & $24 \mathrm{hr}$ \\
\hline 100 & $0.67 \pm 0.00$ & $1.00 \pm 0.33^{\mathrm{a}}$ & $1.67 \pm 0.33^{\mathrm{b}}$ & $2.67 \pm 0.33^{\mathrm{b}}$ & $4.00 \pm 0.57^{\mathrm{ab}}$ & $6.00 \pm 0.57^{\mathrm{b}}$ & $7.33 \pm 0.33^{\mathrm{cb}}$ \\
\hline 50 & $0.00 \pm 0.00$ & $0.00 \pm 0.00^{\mathrm{a}}$ & $1.00 \pm 0.00^{\mathrm{b}}$ & $1.33 \pm 0.33^{\mathrm{ab}}$ & $3.00 \pm 0.00^{c}$ & $5.57 \pm 0.33^{\mathrm{ab}}$ & $6.33 \pm 0.33^{\mathrm{cb}}$ \\
\hline 25 & $0.00 \pm 0.00$ & $0.00 \pm 0.00^{\mathrm{a}}$ & $0.33 \pm 0.33^{\mathrm{a}}$ & $1.00 \pm 0.00^{\mathrm{ab}}$ & $2.33 \pm 0.33^{\mathrm{bc}}$ & $4.33 \pm 0.33^{\mathrm{ab}}$ & $5.33 \pm 0.33^{\mathrm{cb}}$ \\
\hline 12.5 & $0.00 \pm 0.00$ & $0.00 \pm 0.00^{\mathrm{a}}$ & $0.00 \pm 0.00^{\mathrm{a}}$ & $0.67 \pm 0.33^{\mathrm{a}}$ & $2.00 \pm 0.00^{\mathrm{b}}$ & $4.00 \pm 0.00^{\mathrm{b}}$ & $4.33 \pm 0.33^{\mathrm{ab}}$ \\
\hline 6.25 & $0.00 \pm 0.00$ & $0.00 \pm 0.00^{\mathrm{a}}$ & $0.00 \pm 0.00^{\mathrm{a}}$ & $0.33 \pm 0.33^{\mathrm{a}}$ & $1.00 \pm 0.00^{\mathrm{a}}$ & $2.00 \pm 0.33^{\mathrm{ab}}$ & $3.33 \pm 1.45^{\mathrm{cb}}$ \\
\hline $0.1 \%$ diazinon & $0.00 \pm 0.00$ & $0.67 \pm 0.33^{\mathrm{a}}$ & $1.67 \pm 0.33^{\mathrm{a}}$ & $2.67 \pm 0.33^{\mathrm{ab}}$ & $4.67 \pm 0.33^{c}$ & $6.67 \pm 0.33^{\mathrm{ab}}$ & $8.00 \pm 0.00^{\mathrm{cb}}$ \\
\hline Distilled water & $0.00 \pm 0.00$ & $0.00 \pm 0.00^{\mathrm{a}}$ & $0.00 \pm 0.00^{\mathrm{a}}$ & $0.00 \pm 0.00^{\mathrm{a}}$ & $0.00 \pm 0.00^{\mathrm{a}}$ & $0.00 \pm 0.00^{\mathrm{a}}$ & $0.00 \pm 0.00^{\mathrm{a}}$ \\
\hline
\end{tabular}

Means followed by the same letter on the same column are not significantly different by ANOVA $(P>0.05)$. 
TABLE 7: In vitro tick killing effect of methanolic extract of Croton macrostachyus against Rh. pulchellus.

\begin{tabular}{|c|c|c|c|c|c|c|c|}
\hline \multirow{2}{*}{ Extract concentration $(\mathrm{mg} / \mathrm{ml})$} & \multicolumn{7}{|c|}{ Mean number of ticks dead (mean of mortality \pm SE) at minute/hour post exposure } \\
\hline & $30 \mathrm{~min}$ & $1 \mathrm{hr}$ & $2 \mathrm{hr}$ & $3 \mathrm{hr}$ & $6 \mathrm{hr}$ & $12 \mathrm{hr}$ & $24 \mathrm{hr}$ \\
\hline 100 & $0.00 \pm 0.00^{\mathrm{a}}$ & $0.33 \pm 0.33^{\mathrm{a}}$ & $1.33 \pm 0.33^{\mathrm{b}}$ & $1.67 \pm 0.33^{\mathrm{ab}}$ & $2.67 \pm 0.33^{\mathrm{ab}}$ & $5.33 \pm 0.33^{\mathrm{ab}}$ & $7.33 \pm 0.33^{\mathrm{a}}$ \\
\hline 50 & $0.00 \pm 0.00^{\mathrm{a}}$ & $0.00 \pm 0.00^{\mathrm{a}}$ & $1.0 \pm 0.00^{\mathrm{a}}$ & $2.0 \pm 0.57^{\mathrm{ab}}$ & $2.57 \pm 0.33^{\mathrm{b}}$ & $4.67 \pm 0.33^{\mathrm{ab}}$ & $6.00 \pm 0.33^{\mathrm{a}}$ \\
\hline 25 & $0.00 \pm 0.00^{\mathrm{a}}$ & $0.00 \pm 0.00^{\mathrm{a}}$ & $0.33 \pm 0.33^{\mathrm{a}}$ & $1.33 \pm 0.033^{\mathrm{ab}}$ & $2.57 \pm 0.33^{\mathrm{b}}$ & $4.67 \pm 0.57^{\mathrm{ab}}$ & $6.33 \pm 0.33^{\mathrm{a}}$ \\
\hline 12.5 & $0.00 \pm 0.00^{\mathrm{a}}$ & $0.00 \pm 0.00^{\mathrm{a}}$ & $0.00 \pm 0.00^{\mathrm{a}}$ & $0.67 \pm 0.33^{\mathrm{a}}$ & $1.67 \pm 0.33^{\mathrm{ab}}$ & $3.67 \pm 0.33^{\mathrm{b}}$ & $5.0 \pm 0.57^{\mathrm{a}}$ \\
\hline 6.25 & $0.00 \pm 0.00^{\mathrm{a}}$ & $0.00 \pm 0.00^{\mathrm{a}}$ & $0.00 \pm 0.00^{\mathrm{a}}$ & $0.67 \pm 0.33^{\mathrm{a}}$ & $1.00 \pm 0.00^{\mathrm{a}}$ & $2.0 \pm 0.57^{\mathrm{b}}$ & $4.33 \pm 0.67^{\mathrm{a}}$ \\
\hline $0.1 \%$ diazinon & $0.00 \pm 0.00^{\mathrm{a}}$ & $0.67 \pm 0.00^{a}$ & $1.67 \pm 0.33^{\mathrm{a}}$ & $2.67 \pm 0.0 .33^{\mathrm{b}}$ & $5.67 \pm 0.33^{\mathrm{ab}}$ & $7.33 \pm 0.33^{\mathrm{ab}}$ & $9.00 \pm 0.00^{\mathrm{a}}$ \\
\hline Distilled water & $0.00 \pm 0.00^{\mathrm{a}}$ & $0.00 \pm 0.00^{\mathrm{a}}$ & $0.00 \pm 0.00^{\mathrm{a}}$ & $0.00 \pm 0.00^{\mathrm{a}}$ & $0.00 \pm 0.00^{\mathrm{a}}$ & $0.00 \pm 0.00^{\mathrm{a}}$ & $0.00 \pm 0.00^{\mathrm{a}}$ \\
\hline
\end{tabular}

Means followed by the same letter on the same column are not significantly different by ANOVA $(P>0.05)$.

TABLE 8: In vitro tick killing effect of methanolic extract of Nicotiana tabacum against Rh. pulchellus.

\begin{tabular}{|c|c|c|c|c|c|c|c|}
\hline \multirow{2}{*}{ Extract concentration $(\mathrm{mg} / \mathrm{ml})$} & \multicolumn{7}{|c|}{ Mean number of ticks dead (mean of mortality \pm SE) at minute/hour post exposure } \\
\hline & $30 \mathrm{~min}$ & $1 \mathrm{hr}$ & $2 \mathrm{hr}$ & $3 \mathrm{hr}$ & $6 \mathrm{hr}$ & $12 \mathrm{hr}$ & $24 \mathrm{hr}$ \\
\hline 100 & $0.33 \pm 0.33$ & $1.33 \pm 0.33^{\mathrm{a}}$ & $2.57 \pm 0.33^{b}$ & $4.33 \pm 0.33^{\mathrm{b}}$ & $5.0 \pm 0.57^{\mathrm{ab}}$ & $6.33 \pm 0.00^{\mathrm{ab}}$ & $7.67 \pm 0.33^{\mathrm{ab}}$ \\
\hline 50 & $0.00 \pm 0.00$ & $0.00 \pm 0.00^{\mathrm{a}}$ & $0.67 \pm 0.33^{\mathrm{ab}}$ & $1.00 \pm 0.00^{\mathrm{ab}}$ & $3.33 \pm 0.33^{\mathrm{ab}}$ & $4.33 \pm 0.57^{\mathrm{ab}}$ & $6.33 \pm 0.67^{\mathrm{ab}}$ \\
\hline 25 & $0.00 \pm 0.00$ & $0.00 \pm 0.00^{\mathrm{a}}$ & $0.00 \pm 0.00^{\mathrm{a}}$ & $0.67 \pm 0.33^{\mathrm{ab}}$ & $1.33 \pm 0.33^{\mathrm{ab}}$ & $3.33 \pm 0.57^{\mathrm{b}}$ & $5.67 \pm 0.57^{\mathrm{b}}$ \\
\hline 12.5 & $0.00 \pm 0.00$ & $0.00 \pm 0.00^{\mathrm{a}}$ & $0.00 \pm 0.00^{\mathrm{a}}$ & $0.67 \pm 0.33^{\mathrm{ab}}$ & $1.33 \pm 0.57^{\mathrm{ab}}$ & $2.67 \pm 0.67^{\mathrm{ab}}$ & $4.00 \pm 0.57^{\mathrm{ab}}$ \\
\hline 6.25 & $0.00 \pm 0.00$ & $0.00 \pm 0.00^{\mathrm{a}}$ & $0.00 \pm 0.00^{\mathrm{a}}$ & $0.00 \pm 0.00^{\mathrm{ab}}$ & $0.67 \pm 0.33^{\mathrm{ab}}$ & $2.33 \pm 0.33^{\mathrm{ab}}$ & $3.33 \pm 0.33^{\mathrm{ab}}$ \\
\hline $0.1 \%$ diazinon & $0.00 \pm 0.00$ & $0.67 \pm 0.33^{\mathrm{a}}$ & $1.67 \pm 0.33^{\mathrm{ab}}$ & $2.67 \pm 0.33^{\mathrm{ab}}$ & $4.67 \pm 0.33^{\mathrm{b}}$ & $7.67 \pm 0.33^{\mathrm{ab}}$ & $8.00 \pm 0.00^{\mathrm{ab}}$ \\
\hline Distilled water & $0.00 \pm 0.00$ & $0.00 \pm 0.00^{\mathrm{a}}$ & $0.00 \pm 0.00^{\mathrm{a}}$ & $0.00 \pm 0.00^{\mathrm{a}}$ & $0.00 \pm 0.00^{\mathrm{a}}$ & $0.00 \pm 0.00^{\mathrm{a}}$ & $0.00 \pm 0.00^{\mathrm{a}}$ \\
\hline
\end{tabular}

Means followed by the same letter on the same column are not significantly different by ANOVA $(P>0.05)$.

types and quantities of secondary metabolites derived from natural sources that are subject to variability [35].

The current study revealed that the mean mortality of adult ticks was increased significantly with increased dosage (concentration) and exposure time after in vitro treatment for the tested botanicals. This result is in line with the findings of Qwarse [36] and Gebre-Egziabiher [37] in which mortality effect of botanicals was indicated to be dose concentration- and exposure time-dependent. Our study also revealed that all methanolic extracts of the tested botanical leaves at tested concentrations induced significant acaricidal effect against $B$. decoloratus compared with the negative control.

The in vitro tick killing activity of methanolic leaf extracts of $C$. aurea is increased with increased concentrations and time exposure (Table 3). After $24 \mathrm{hr}$ post exposure, C. aurea showed high mortality $(8.33 \pm 0.33)$ at concentrations of $100 \mathrm{mg} / \mathrm{ml}$ which was comparable with $0.1 \%$ diazinon (positive control) $(9.00 \pm 0.00)$. All concentrations of $C$. aurea showed tick killing effects at different concentrations and time exposure compared with the negative control. The present result is comparable with those obtained using different species of ticks reported by some researchers. Fouche et al. [38] reported that the acetone extract of $C$. aurea (leaves and flowers) had mortality effect of $92.2 \%$ while the ethanol extract had $81.1 \%$ mortality against $R$. turanicus. Similarly, Zorloni et al. [25] reported that $20 \%$ and $10 \%$ acetone leaf extracts for C. aurea either kill or severely compromise the movement of unfed adult Rh. pulchellus ticks. Regassa [9] found $10 \%$ tick mortality at $5 \mathrm{hr}$ exposure of aqueous leaf and bark extracts of $C$. aurea. Differences among these studies might be due to the difference in solvent used for extraction as studies have shown that organic solvent extracts show greater biological activity than the aqueous extract [39].

Similar to C. aurea, S. molle showed good in vitro tick killing effect. As concentration and exposure time increased, mortality of $R h$. decoloratus was also increased. At the highest concentration $(100 \mathrm{mg} / \mathrm{ml})$, the killing effect of the plant was comparable to the positive control. All concentrations of $S$. molle including the least concentrations had effects on ticks when compared with the negative control (Table 4). In addition, especially for concentrations of $100 \mathrm{mg} / \mathrm{ml}$, $50 \mathrm{mg} / \mathrm{ml}$, and $25 \mathrm{mg} / \mathrm{ml}$, more than $50 \%$ of tick mortality was observed as early as $12 \mathrm{hr}$ post exposure to the extracts. Generally, a positive correlation was noted between graded concentrations of the extracts, the exposure test-time interval, and tick mortality (Figure 1). Feyera and Abdisa [12] recorded that the crude aqueous extracts of $S$. molle produced $100 \%$ for Boophilus adult mortality rates at concentrations of $1 \mathrm{~g} / 25 \mathrm{ml}$ after $24 \mathrm{hr}$ of exposure. Such difference might be due to test solvents used to extract plant and doses applied.

The leaf extracts of $V$. amygdalina showed moderate antitick activity against $B$. decoloratus at higher concentration $(100 \mathrm{mg} / \mathrm{ml})$ and have little activity at least concentration $(6.25 \mathrm{mg} / \mathrm{ml})$ after $24 \mathrm{hr}$ post exposure. Kumar et al. [33] and Ghosh et al. [40] have reported that similar methanolic 
extract of the plant has potent activity on $R h$. decoloratus even at lower concentrations. This finding is incompatible with Askale [11] who found no mortality of $B$. decoloratus with leaf extracts of $V$. amygdalina at $6.25 \mathrm{mg} / \mathrm{ml}$ after $24 \mathrm{hr}$ post exposure. The presence of efficacy at low concentration in this finding may be attributed to differences in methodology. It could also be related to the nature of the plant at the time of collection [41]. The acaricidal activity of this plant may be due to the presence of the phytochemical ingredients found in it.

Methanolic extract of R. communis leaf had good acaricidal activity (73\%) against $R$. pulchellus at $100 \mathrm{mg} / \mathrm{ml}$ concentration. Kumar et al. [42] had reported that similar methanolic extract of the plant has potent activity on $R h$. pulchellus even at lower concentrations. It has been reported that the high toxicity of $R$. communis extracts against ticks was due to the presence of bioactive in the extracts [43]. The results obtained in the present study indicated that C. macrostachyus and N. tabacum had similar acaricidal efficacy on $R h$. pulchellus with $R$. communis. In line with this finding, Kumar et al. [33] and Ghosh et al. [40] had reported that similar activity of methanolic extract of the plant had shown on Rh. pulchellus even at lower concentrations. Different constituents of the plants screened may be responsible for the toxic effect of the extracts that caused mortality of Rh. pulchellus $[44,45]$. N. tabacum was used in the ethnoveterinary practice as an anthelmintic [46], antirheumatic agent, and anti-inflammatory [47]. Phytochemical screening of the various solvent extracts of $N$. tabacum leaves revealed that the plant contains tannins, phenolic compounds, steroids, flavonoids, phlobatannin, and alkaloids.

Comparative in vitro acaricidal activity of crude extracts of the plants revealed higher mortality of ticks exposed to C. aurea (83\%) and S. molle (83\%) compared with $N$. tabacum $(77 \%), V$. amygdalina $(76 \%), R$. communis (73\%), and C. macrostachyus (73\%) after $24 \mathrm{hrs}$ of exposure at $100 \mathrm{mg} / \mathrm{ml}$ concentration. The difference in mortality percentage of these plants might be due to variability on the amount of secondary metabolites among the plant extracts. The phytochemical analysis in this study showed that C. aurea has more secondary metabolites than others. In this study, the relatively lower acaricidal activity of $N$. tabacum, V. amygdalina, R. communis, and C. macrostachyus compared to C. aurea and S. molle might be due to lower quantity of secondary metabolites [48]. Studies indicate the presence of alkaloid, glycosides, and phenol as important chemicals to initiate the mechanism of action in in vitro and in vivo activities causing mortality against ticks [33]. Comparable tick mortality that was obtained by the positive control group (diazinon) might be possible with the studied leaf extract, although there is great variation in time between them. However, due to their cost effectiveness and availability in the rural area, leaves of these plants could be an excellent acaricidal option.

\section{Conclusions}

Extracts of C. aurea, S. molle, V. amygdalina, R. communis, C. macrostachyus, and N. tabacum were tested against
Rh. (B). decoloratus and Rh. pulchellus for their killing efficacy at different concentrations and time intervals. The findings suggest that the crude methanol extracts of the plants contain secondary metabolites with high acaricidal activity properties. It was observed that except $R$. communis and C. macrostachyus, which had moderate acaricidal activity, the remaining plants particularly C. aurea and S. molle had strong acaricidal activity greatly comparable to the effect of $0.1 \%$ diazinon at higher concentrations. Efficacy of the extracts increases with increasing concentration and exposure time. Therefore, the present study concluded that the tested medicinal plants showed promising killing effect against $R h .(B)$. decoloratus and $R h$. pulchellus that could be used as the potential alternative to substitute commercially available drugs. For those extracts that have shown high promising results, in vivo toxicity and efficacy test should be done to validate the importance of the materials in order to formulate and incubate the products obtained.

\section{Data Availability}

Vouchers and dried plant materials used for this study are stored at the Herbarium of the Department of Plant Science, Haramaya University, Ethiopia. The datasets supporting the conclusion of this study are available from the corresponding author on reasonable request.

\section{Conflicts of Interest}

The authors declare that they have no conflicts of interest.

\section{Authors' Contributions}

Jelalu Kemal and Teka Feyera conceived, designed, and coordinated the study including the process of earning fund. Kedir Sali and Musa Nasir conducted the experiments. Jelalu Kemal, Kedir Sali, Musa Nasir, Tesfaheywet Zerihun, Sisay Alemu, and Ashebr Abraha participated in data collection and writing up of the manuscript. Jelalu Kemal and Teka Feyera participated in data analysis, result interpretation, and drafting of the manuscript. Jelalu Kemal finalized and submitted the manuscript for publication. All authors approved the final manuscript. All coauthors have consented for the publication of this manuscript.

\section{Acknowledgments}

The authors would like to acknowledge the Office of the Research Affairs, Haramaya University, for funding this project.

\section{References}

[1] S. M. Habeeb, "Ethno-veterinary and medical knowledge of crude plant extracts and its method of application (traditional and modern) for tick control," World Applied Sciences Journal, vol. 11, no. 9, pp. 1047-1054, 2010.

[2] F. Nchu, S. R. Magano, and J. N. Eloff, "In vitro anti-tick properties of the essential oil of Tagetes minuta L. (Asteraceae) on 
Hyalomma rufipes (Acari: Ixodidae)," Onderstepoort Journal of Veterinary Research, vol. 79, no. 1, 2012.

[3] A. A. Walker, A. Bouatour, J. L. Camicas et al., Ticks of Domestic Animals in Africa: A Guide to Identification Species, The University of Edinburgh, UK, 2003.

[4] K. H. Pirali-Kheirabadi and J. T. da Silva, "In-vitro assessment of the acaricidal properties of Artemisia annua and Zataria multiflora essential oils to control cattle ticks," Iranian Journal of Parasitology, vol. 6, no. 1, pp. 58-65, 2011.

[5] J. Yilma, G. Adamu, and E. Zerbini, "Bioassay of acaricide resistance on three common cattle tick species at Holotta, Central Ethiopia," Revue De Medecine Veterinaire, vol. 152, no. 7, p. 385, 2001.

[6] M. Sileshi, A. Kgasi, W. Mureithi et al., "In vivo and in-vitro evaluation of the efficacy of Cypermethin High-Cis (Ecotomin) against cattle ticks in Ethiopia," Ethiopian Veterinary Journal, vol. 8, no. 1, pp. 29-38, 2004.

[7] A. Petros, U. W. Befekadu, M. Mulisa, and F. Teka, "In vitro and in vivo acaricidal efficacy study of amitraz and diazinon against some tick species infesting Camelus dromedarius around Jigiga, Eastern Ethiopia," African Journal of Pharmacy and Pharmacology, vol. 9, no. 34, pp. 850-855, 2015.

[8] J. Madzimure, E. T. Nyahangare, H. Hamudikuwanda et al., "Acaricidal efficacy against cattle ticks and acute oral toxicity of Lippia javanica (Burm F.) spreng," Tropical Animal Health and Production, vol. 43, no. 2, pp. 481-489, 2011.

[9] A. Regassa, "The use of herbal preparations for tick control in western Ethiopia," Journal of the South African Veterinary Association, vol. 71, no. 4, pp. 240-243, 2000.

[10] A. Teklay, B. Abera, and M. Giday, "An ethnobotanical study of medicinal plants used in Kilte Awulaelo District, Tigray region of Ethiopia," Journal of Ethnobiology and Ethnomedicine, vol. 9, no. 1, p. 65, 2013.

[11] G. Askale, In vitro effecacy of methanolic extracts of Vernonia amygdalina, Croton macrostachyus, Ricinus communis and petroleum ether extract of Millettia ferruginea against Bovicola ovis and Rhipicephalus (boophilus) decoloratus, [M.S. thesis], Addis Ababa University, Ethiopia, 2015.

[12] T. Feyera and E. Abdisa, "In vitro acaricidal activity of crude extracts of Schinus molle (L.) leaves against field population of Bophilus decoloratus and Rhipicephalus pulchellus ticks," African Journal of Pharmacy and Pharmacology, vol. 10, no. 36, pp. 772-777, 2016.

[13] D. E. Dula and A. Zelalem, "Phytochemical screening of Calpurnia aurea root extract," Kenkyu Journal of Pharmacy Practice \& Health Care, vol. 4, 2018.

[14] M. K. Kalume, B. Losson, L. Angenot et al., "Rotenoid content and in vitro acaricidal activity of Tephrosia vogelii leaf extract on the tick Rhipicephalus appendiculatus," Veterinary Parasitology, vol. 190, no. 1-2, pp. 204-209, 2012.

[15] B. Vongkhamchanh, R. Paweena, and B. Prapassorn, "Acaricidal activities of crude extract derived from Annona squamosa Linnaeus leaves against cattle tick, Rhipicephalus microplus Canestrini (Acari: Ixodidea)," Journal of Science and Technology, Mahasarakham University, vol. 33, no. 2, pp. 211-216, 2013.

[16] A. Zorloni, Evaluation of plants used for the control of animal ectoparasites in southern Ethiopia Oromiya and Somalia regions, [M.S. thesis], University of Pretoria, South Africa, 2007.
[17] A. Sofowora, Medicinal Plants and Traditional Medicine in Africa, Spectrum Books Ltd, Ibadan, Nigeria, 1993.

[18] A. R. Walker, A. Bouattour, J. L. Camicas et al., "Ticks of domestic animals in Africa: a guide to identification of species," Bioscience Reports, p. 221, 2007.

[19] J. Heukelbach, R. Speare, and D. Canyon, "Natural products and their application to the control of head lice: an evidencebased review," in Chemistry Natural Products: Recent Trend and Developments, G. Brahmachari, Ed., pp. 227-302, Research Signpost, Kerala, India, 2006.

[20] M. A. Zaman, Z. Iqbal, R. Z. Abbas et al., "In vitro and in vivo acaricidal activity of a herbal extract," Veterinary Parasitology, vol. 186, no. 3-4, pp. 431-436, 2012.

[21] Y.-H. Du, R.-Y. Jia, Z.-Q. Yin et al., "Acaricidal activity of extracts of neem (Azadirachta indica) oil against the larvae of the rabbit mite Sarcoptes scabiei var. cuniculi in vitro," Veterinary Parasitology, vol. 157, no. 1-2, pp. 144-148, 2008.

[22] S. Krishnaveni and P. Venkatalakshmi, "Antimicrobial, larvicidal and acaricidal activities of the ethanolic extract of andrographis paniculata and carica papaya leaves," World Journal Pharmacology Research, vol. 3, pp. 660-669, 2014.

[23] C. Marie-Magdeleine, H. Hoste, M. Mahieu, H. Varo, and H. Archimede, "In vitro effects of Cucurbita moschata seed extracts on Haemonchus contortus," Veterinary Parasitology, vol. 161, no. 1-2, pp. 99-105, 2009.

[24] S. Umer, A. Tekewe, and N. Kebede, "Antidiarrhoeal and antimicrobial activity of Calpurnia aurea leaf extract," BMC Complementary and Alternative Medicine, vol. 13, 2013.

[25] A. Zorloni, B. L. Penzhorn, and J. N. Eloff, "Extracts of Calpurnia aurea leaves from southern Ethiopia attract and immobilise or kill ticks," Veterinary Parasitology, vol. 168, no. 1-2, pp. 160-164, 2010.

[26] A. A. Adedapo, F. O. Jimoh, S. Koduru, J. A. Afolayan, and P. Masika, "Antimicrobial and antioxidant properties of the methanol extracts of leaves and stems of Calpurnia aurea," BMC Complementary and Alternative Medicine, vol. 8, no. 53, pp. 1-8, 2008.

[27] S. Magadum, D. B. Mondal, and S. Ghosh, "Comparative efficacy of Annona squamosa and Azadirachta indica extracts against Boophilus microplus Izatnagar isolate," Parasitology Research, vol. 105, no. 4, pp. 1085-1091, 2009.

[28] V. L. S. Ribeiro, C. Avancini, K. Gonçalves, E. Toigo, and G. von Poser, "Acaricidal activity of Calea serrata (Asteraceae) on Boophilus microplus and Rhipicephalus sanguineus," Veterinary Parasitology, vol. 151, no. 2-4, pp. 351-354, 2008.

[29] G. A. Ayoola, H. A. Coker, S. A. Adesegun et al., "Phytochemical screening and antioxidant activities of some selected medicinal plants used for malaria therapy in Southwestern Nigeria," Tropical Journal of Pharmaceutical Research, vol. 7, no. 3, pp. 1019-1024, 2008.

[30] O. L. Adebayo, A. James, S. B. Kasim, and O. P. Jagri, "Leaf extracts of Vernonia amygdalina Del. from northern Ghana contain bioactive agents that inhibit the growth of some beta-lactamase producing bacteria in vitro," British Journal of Pharmaceutical Research, vol. 4, no. 2, pp. 192-202, 2014.

[31] L. Alemu, E. Desta, and L. K. Degu, "Isolation of sesquiterpene from the leaves extract of Vernonia amygdalina and its acute toxicity to the albino mice," Chemistry and Materials Research, vol. 8 , no. 6,2016 . 
[32] R. K. Singh, M. K. Gupta, A. K. Singh, and S. Kumar, "Pharmacognostical investigation of Ricinus communis stem," International Journal of Pharmaceutical Sciences and Research, vol. 1, no. 6, pp. 89-94, 2010.

[33] A. Kumar, S. Singh, K. Mahour, and V. S. Vihan, "In-vitro and In-vivo acaricidal activity of some indigenuos plants under organized and farmed flock," Pharmacology Online, vol. 3, pp. 361-369, 2011.

[34] A. Heimerdinger, O. C. J. Oliv, M. B. Molento et al., "Extrato alcoolico de Capim-cidreira (Cymbopogon citratus) no controle do Boophilus microplus em bovinos," Revista Brasileira de Parasitologia Veterinária, vol. 15, no. 1, pp. 37-39, 2006.

[35] C. U. Solomon, U. I. Arukwe, and I. Onuoha, "Preliminary phytochemical screening of different solvent extracts of stem bark and roots of Dennetia tripetala," Asian Journal of Plant Science and Research, vol. 3, no. 3, pp. 10-13, 2013.

[36] M. Qwarse, Assessment of bioactivity of selected plants against pests and microbes from agro-pastoral communities in Mbulu district, [M.S. thesis], Open University of Tanzania, 2015.

[37] K. G. Gebre-Egziabiher, Evaluation of some botanicals and sorghum varieties and landraces for the management of maize weevil, Sitophilus zeamais Motsch. (Coleoptera: Curculionidae), [M.S. thesis], Haramaya University, 2016.

[38] G. Fouche, B. M. Sakong, O. T. Adenubi et al., "Investigation of the acaricidal activity of the acetone and ethanol extracts of 12 South African plants against the adult ticks of Rhipicephalus turanicus," Onderstepoort Journal of Veterinary Research, vol. 84, no. 1, article 1523, 2017.

[39] S. V. Chanda and J. Parekh, "In vitro antimicrobial activity and phytochemical analysis of some Indian medicinal plants," Turkish Journal of Biology, vol. 31, pp. 53-58, 2007.

[40] S. Ghosh, S. S. Tiwari, S. Srivastava et al., "Acaricidal properties of Ricinus communis leaf extracts against organophosphate and pyrethroids resistant Rhipicephalus (Boophilus) microplus," Veterinary Parasitology, vol. 192, no. 1-3, pp. 259-267, 2013.

[41] A. Pandey and T. Shalini, "Concept of standardization, extraction and pre phytochemical screening strategies for herbal drug," Journal of Pharmacognosy and Phytochemical, vol. 2, pp. 115-119, 2014.

[42] M. K. Choudhury, Y. Shiferaw, and A. Hussen, "Toxicity of Millettia ferruginea darasana (family: Fabaceae) against the larvae and adult ticks of Amblyomma variegatum Fabricius a three-host tick in cattle," Journal of Parasitic Diseases, vol. 39, no. 2, pp. 298-302, 2015.

[43] A. K. Tounou, G. Mawussi, S. Amadou et al., "Bio-insecticidal effects of plant extracts and oil emulsions of Ricinus communis L. (Malpighiales: Euphorbiaceae) on the diamondback, Plutella xylostella L. (Lepidoptera: Plutellidae) under laboratory and semifield conditions," Journal of Applied Biosciences, vol. 43, pp. 2899-2914, 2011.

[44] Z. M. Yibralign, Phytochemical investigation on the stem bark of Croton macrostachyus (Bisana), [M.S. thesis], Addis Ababa University, Department of Chemistry, Ethiopia, 2007.

[45] B. I. Okeleye, P. O. Bessong, and R. N. Ndip, "Preliminary phytochemical screening and In Vitro anti-Helicobacter pylori activity of extracts of the stem bark of Bridelia micrantha (Hochst., Baill., Euphorbiaceae)," Molecules, vol. 16, no. 8, pp. 6193-6205, 2011.

[46] Z. Iqbal, M. Lateef, A. Jabbar, M. N. Ghayur, and A. H. Gilani, "In vitro and In vivo anthelmintic activity of Nicotiana taba- cum L. leaves against gastrointestinal nematodes of sheep," Phytotherapy Research, vol. 20, no. 1, pp. 46-48, 2006.

[47] K. M. Nadkarni, Indian Materia Medica, Popular Prakashan: Bombay, Mumbai, India, 1976.

[48] S. Ghosh, S. S. Tiwari, B. Kumar et al., "Identification of potential plant extracts for anti-tick activity against acaricide resistant cattle ticks, Rhipicephalus (Boophilus) microplus (Acari: Ixodidae)," Experimental and Applied Acarology, vol. 66, no. 1, pp. 159-171, 2015. 